\title{
Cogongrass (Imperata cylindrical L.) Roots Ethanol Extract to Improve Hematological Profile in Carbon Tetrachloride-Injection Mice Model
}

\author{
Anisah Dahlan, ${ }^{1}$ Fitria Hariati Ramdhani, ${ }^{2}$ Neni Anggraeni, ${ }^{3}$ Irma Melyani Puspitasari, ${ }^{4}$ \\ Mirasari Putri, ${ }^{5}$ Mas Rizky A. A. Syamsunarno ${ }^{1,2,6}$ \\ ${ }^{1}$ Department of Biomedical Sciences, Faculty of Medicine, Universitas Padjadjaran, Sumedang, Indonesia, \\ ${ }^{2}$ Master of Biotechnology Study Program, Postgraduate School, Universitas Padjadjaran, Bandung, Indonesia, \\ ${ }^{3}$ Medical Laboratory Technologist, Bakti Asih School of Analyst, Bandung, Indonesia, ${ }^{4}$ Department of \\ Pharmacology and Clinical Pharmacy, Faculty of Pharmacy, Universitas Padjadjaran, Sumedang, Indonesia, \\ ${ }^{5}$ Department of Biochemistry, Faculty of Medicine, Universitas Islam Bandung, Bandung, Indonesia, \\ ${ }^{6}$ Central Laboratory, Universitas Padjadjaran, Sumedang, Indonesia
}

\begin{abstract}
Carbon tetrachloride $\left(\mathrm{CCL}_{4}\right)$ is widely used in industry, toxic to the environment and humans, and most often used as a model of acute liver damage and liver fibrosis in experimental animals. Liver damage can deteriorate the hematological profile. The roots of cogongrass (Imperata cylindrica L.) have been used as traditional medicine due to its antioxidant activity. This study was conducted at the Faculty of Medicine, Universitas Padjadjaran, from January to March 2019. The study aimed to investigate whether the cogongrass roots ethanol extract (CGRE) can ameliorate the disturbance in the hematological profile in acute $\mathrm{CCl}_{4}$-injected mice. CGRE in dose 150 and 200 $\mathrm{mg} / \mathrm{kgBW}$ was given orally to mice for four weeks before intraperitoneal injection of $\mathrm{CCl}_{4} 1 \mathrm{~mL} / \mathrm{kgBW}$ in olive oil $(1: 1 \mathrm{v} / \mathrm{v})$. After 48 hours, mice were sacrificed, and the whole blood was drawn for hematological analysis. As a result, mean corpuscular volume (MCV) was reduced in $\mathrm{CCl}_{4}$-induction mice treated with CGRE in dose $150 \mathrm{mg} /$ $\mathrm{kgBW}(49.25 \pm 3.06$ vs $43.38 \pm 2.13 \mathrm{fl}, \mathrm{p}<0.05)$. This condition was followed by the improved hematocrit (Hct) and mean corpuscular hemoglobin concentration (MCHC). Platelet and platelet crit (Pct) levels were tended to decrease in $\mathrm{CCl}_{4}$-induction mice treated with CGRE in dose $150 \mathrm{mg} / \mathrm{kgBW}$. In conclusion, CGRE dose $150 \mathrm{mg} / \mathrm{kg} \mathrm{BW}$ can improve $\mathrm{MCV}$, Hct, $\mathrm{MCHC}$, platelet, and Pct in $\mathrm{CCl}_{4}$-injection mice. The antioxidant level in CGRE might facilitate it.
\end{abstract}

Keywords: Antioxidant, carbon tetrachloride, cogongrass roots, hematological profile, liver damage

\section{Ekstrak Etanol Akar Alang-alang (Imperata cylindrical L.) Memperbaiki Profil Hematologi pada Mencit yang Diinjeksi Carbon Tetrachloride}

\begin{abstract}
Abstrak
Carbon tetrachloride $\left(\mathrm{CCL}_{4}\right)$ banyak digunakan pada industri, bersifat toksik bagi lingkungan dan manusia, serta sering digunakan pada hewan coba untuk kerusakan liver akut dan fibrosis. Kerusakan liver dapat menyebabkan gangguan profil hematologi. Akar alang-alang (Imperata cylindrica L.) telah digunakan sebagai obat tradisional karena memiliki aktivitas antioksidan. Penelitian ini dilakukan di Fakultas Kedokteran Universitas Padjadjaran pada bulan Januari hingga Maret 2019. Tujuan penelitian ini adalah meneliti apakah ekstrak etanol akar alangalang dapat memperbaiki gangguan profil hematologi pada mencit yang diinjeksi $\mathrm{CCL}_{4}$ secara akut. Ekstrak etanol akar alang-alang (EEAA) dosis 150 dan $200 \mathrm{~mm} / \mathrm{kgBB}$ diberikan per oral kepada mencit selama empat minggu sebelum injeksi intraperitoneal $\mathrm{CCl}_{4} 1 \mathrm{~mL} / \mathrm{kgBB}$ yang dilarutkan dalam minyak zaitun (1:1 v/v). Setelah 48 jam, mencit dikorbankan dan diambil darahnya untuk pemeriksaan hematologi. Sebagai hasil, mean corpuscular volume $(\mathrm{MCV})$ menurun pada mencit yang diinduksi $\mathrm{CCl}_{4}$ dengan perlakuan EEAA $150 \mathrm{mg} / \mathrm{kgBB}(49,25 \pm 3,06 \mathrm{vs}$ $43,38 \pm 2,13 \mathrm{fl}, \mathrm{p}<0,05)$. Keadaan ini diikuti dengan perbaikan hematokrit (Hct) dan mean corpuscular hemoglobin concentration (MCHC). Kadar platelet dan platelet crit (Pct) cenderung menurun pada mencit yang diinduksi $\mathrm{CCl}_{4}$ dengan perlakuan EEAA $150 \mathrm{mg} / \mathrm{kgBB}$. Sebagai simpulan, EEAA dosis $150 \mathrm{mg} / \mathrm{kgBB}$ dapat memperbaiki MCV, Hct, MCHC, platelet dan Pct pada mencit yang diinjeksi CCL4. Kemungkinan difasilitasi oleh antioksidan pada EEAA.
\end{abstract}

Kata kunci: Akar alang-alang, antioksidan, carbon tetrachloride, kerusakan liver, profil hematologi

Received: 30 August 2020; Revised: 6 December 2020; Accepted: 17 December 2020; Published: 31 December 2020

Correspondence: Mas Rizky A. A. Syamsunarno, dr., M.Kes, Ph.D. Department of Biomedical Sciences, Faculty of Medicine, UniversitasPadjadjaran. Jln. Raya Bandung-Sumedang km 21, Jatinangor, Sumedang 45363, West Java, Indonesia. E-mail: rizky@ unpad.ac.id 


\section{Introduction}

Tissue damage can be caused by an increase in oxidative stress, where the production of reactive oxygen species (ROS) is higher than antioxidants in the body. ${ }^{1}$ ROS originates from the body's biological process, such as by-products of the electron transport chain and oxidase and peroxidase enzymatic activity. ROS production can also come from external exposure, such as organic solvent chemicals and pollution. ${ }^{2,3}$ Carbon tetrachloride $\left(\mathrm{CCL}_{4}\right)$ is chlorinated hydrocarbon solvents widely used in industry and can be toxic to the environment and humans. ${ }^{4} \mathrm{CCL}_{4}$ is a chemical that can cause liver damage and is most often used as a model of acute liver damage and liver fibrosis in experimental animals. ${ }^{5-7} \mathrm{The} \mathrm{CCl}_{4}$ from circulation that goes to the liver is converted by cytochrome P-450 (CYP2E1), forming trichloromethyl free radicals $\left(\mathrm{CCl}_{3}\right)$ and further converted to trichloromethyloxy radical $\left(\mathrm{CCl}_{3} \mathrm{O}_{2}\right)$ which has more radical properties. ${ }^{8,9}$ These radicals then attack cellular macromolecules and cause peroxidation of lipid, protein degradation, and DNA damage. This process is followed by the release of liver inflammatory cytokines such as interleukin-1 $\beta$ (IL-1 $\beta$ ) and tumor necrosis factor- $\alpha$ (TNF- $\alpha$ ), which ultimately leads to liver cell damage. ${ }^{6}$

The liver is an organ that plays a role in hematopoiesis. Damage to the liver cells causes the liver not to function normally so that the hematopoiesis system is disrupted. Anemia and thrombocytopenia are common findings in a patient with liver damage. ${ }^{10,11}$ The anemia is caused by bleeding due to thrombocytopeniainduced coagulopathy, the shortening of erythrocytes' life span, and reduction of red blood cell production in the bone marrow. These phenotypes also occur in liver damage animal models. For example, chronic intraperitoneal injection of $\mathrm{CCl}_{4}$-induced hepatic damages can disrupt hematological profile in rats showed by anemia, thrombocytopenia, and leucocytosis. ${ }^{12,13}$

Studies showed that plant extracts benefit from protecting the liver from damage and further complication of liver damage. For example, basil extract (Ocimum basilicum) ameliorates liver damage in the $\mathrm{CCl}_{4}$-injection rats model showed decreased fibrosis signs and liver enzyme marker reduction and peroxidation activity. ${ }^{14}$ Other extract plants, Cnidoscolus aconitifolius, leaves extract, Teucrium polium aqueous extract, and Mangifera indica leaves extract has been identified to protect rats from hematology deterioration caused by $\mathrm{CCl}_{4}$-injection rat. ${ }^{12,13,15}$ These extract plants contain high flavonoids derivate that have the ability as an antioxidant to protect cells from free radical. ${ }^{16}$

Cogongrass (Imperata cylindrica L.) or alang-alang (Indonesian language) is a weed species invasively cultivated in tropical areas. Cogongrass roots have been used as a traditional medicine to treat fever and as a tonic due to their antioxidant activity. ${ }^{16-18}$ The extract ethanol of cogongrass roots (CGRE) has bioactive compounds, including flavonoid, isoflavone, and flavonol that play an antioxidant role. ${ }^{16} \mathrm{We}$ suggested CGRE can ameliorate disturbance in hematological profile due to liver damage. Thus, the study aimed to investigate whether CGRE can ameliorate disturbance in hematological profile in acute $\mathrm{CCl}_{4}$-induced liver damage animal model.

\section{Methods}

Cogongrass roots were obtained from Garut, West Java, and were identified by the School of Life Sciences, Institut Teknologi Bandung. Cogongrass roots were madepowder and extracted using $96 \%$ ethanol (Merck, Japan) through a 72hour maceration process. Maceration results were filtered and concentrated with the freezedrying technique. The yield of CGRE products was diluted using $0.5 \%$ carboxymethyl cellulose (CMC, Merck, Japan).

Eight-week-old male mice were obtained from the Animal Laboratory, PT Bio Farma, Bandung, Indonesia. The study was conducted at the Faculty of Medicine, Universitas Padjadjaran, from January to March 2019 after obtaining approval from the Research Ethics Committee Universitas Padjadjaran (Number 1353/UN6.KEP/EC/2018). Mice were placed in a temperature-controlled room, 12-hour light, and 12-hour dark cycle and had unlimited access to water and food. Mice were divided into four groups; group I (as normal control) and II (as a negative control) were given $200 \mu \mathrm{L} 0.5 \%$ CMC orally. Group III was given CGRE at a dose of $150 \mathrm{mg} / \mathrm{kg}$ Body Weight (BW) in $200 \mu \mathrm{L} \mathrm{CMC} 0.5 \%$, and group IV were given CGRE at a dose of $200 \mathrm{mg} / \mathrm{kgBW}$ in $200 \mu \mathrm{L} \mathrm{CMC}$ $0.5 \%$. The treatment was carried out for 28 days. Considering the high damage caused by $\mathrm{CCl}_{4}$, the dose was doubled from the previous study to gain more flavonoid compounds. ${ }^{19}$ After four 
weeks of treatment, groups II, III, and IV were given an injection of $\mathrm{CCL}_{4} 1 \mathrm{~mL} / \mathrm{kgBW}$ in olive oil $(1: 1 \mathrm{v} / \mathrm{v}) .^{7}$ After 48 hours of induction; mice were terminated for blood collection by injection of ketamine-xylazine. Blood was drawn out through the abdominal portal vein as much as $100 \mu \mathrm{L}$ and transferred into the EDTA microtube (BD, U.S.A.). The examination of 14 parameters of the hematology profile was conducted using the hematology analyzer machine (Samsung Labgeo HC-10).

Statistical analysis was performed by using GraphPad Prism 8. Data normality analysis was performed using the Shapiro-Wilk test of the normality test method. Analysis of variance (ANOVA) was used to analyze data among groups, followed by the Bonferroni post hoc test. Values are expressed as mean \pm standard deviation with significant level $\mathrm{p}<0.05$.

\section{Results}

The results of hematological examination related to the profile of red blood cells are shown in Table 1. The total red blood cell examination (RBC) and hemoglobin did not show significant differences between groups after $\mathrm{CCL}_{4}$ induction. There was a significant increase in hematocrit in $\mathrm{CCl}_{4}$ compared to group I $(\mathrm{p}<0.05)$, but no change in the group given CGRE (groups III and IV). There was a significant increase in MCV values and decreased MCHC in group II compared to group I. However, the administration of CGRE significantly improved MCV and MCHC to the normal value in group I. There were no significant differences between groups in the mean corpuscular hemoglobin $(\mathrm{MCH})$ value.

The results of hematological parameters related to white blood cells showed no increase in white blood cells' components 48 hours after CCL4 induction (Table 2). CGRE administration did not change the value of total white blood cells (WBC), lymphocytes, monocytes, and granulocytes. Consistent with these results, the percentage value of white blood cell groups, i.e., \% lymphocytes, \% monocytes, and \% granulocytes, did not differ significantly after CGRE administration.

The profile of hematological examination related to platelet parameters is shown in Table 3 . The induction of $\mathrm{CCl}_{4}$ significantly increased the platelet and platelet crit (Pct) values by almost three times $(\mathrm{p}<0.05)$. However, the mean platelet volume (MPV) and platelet distribution width

Table 1 Red Blood Cells Parameters

\begin{tabular}{lcccccc}
\hline Groups & $\begin{array}{c}\mathbf{R B C} \\
\left(\mathbf{1 0}^{\mathbf{6}} / \boldsymbol{\mu L}\right)\end{array}$ & $\begin{array}{c}\mathbf{H b} \\
(\mathbf{g} / \mathbf{d L})\end{array}$ & $\begin{array}{c}\text { Het } \\
\mathbf{( \% )}\end{array}$ & $\begin{array}{c}\text { MCV } \\
(\mathbf{f l})\end{array}$ & $\begin{array}{c}\mathbf{M C H} \\
(\mathbf{p g})\end{array}$ & $\begin{array}{l}\text { MCHC } \\
(\mathbf{g} / \mathbf{d L})\end{array}$ \\
\hline Group I & $8.60 \pm 1.85$ & $13.69 \pm 2.03$ & $37.37 \pm 7.48^{\mathrm{a}}$ & $43.71 \pm 2.56^{\mathrm{a}}$ & $16.24 \pm 1.71$ & $37.14 \pm 2.82^{\mathrm{a}}$ \\
Group II & $9.44 \pm 0.36$ & $15.09 \pm 1.17$ & $46.61 \pm 4.24^{\mathrm{a}}$ & $49.25 \pm 3.06^{\mathrm{a}, \mathrm{b}}$ & $15.96 \pm 0.93$ & $32.17 \pm 1.11^{\mathrm{a}, \mathrm{b}}$ \\
Group III & $9.72 \pm 1.00$ & $14.86 \pm 1.38$ & $41.97 \pm 3.09$ & $43.38 \pm 2.13^{\mathrm{b}}$ & $15.34 \pm 0.87$ & $35.36 \pm 1.01^{\mathrm{b}}$ \\
Group IV & $9.24 \pm 1.06$ & $14.10 \pm 1.99$ & $40.99 \pm 7.05$ & $44.29 \pm 3.86$ & $15.21 \pm 0.68$ & $34.64 \pm 2.55$ \\
\hline
\end{tabular}

Note: the same letter in superscript at the same column indicates statistically significant $(\mathrm{p}<0.05) . \mathrm{RBC}=\mathrm{red}$ blood cells; $\mathrm{Hb}=$ hemoglobin; Hct=hematocrit; $\mathrm{MCV}=$ mean corpuscular volume; $\mathrm{MCH}=$ mean corpuscular hemoglobin; $\mathrm{MCHC}=$ mean corpuscular hemoglobin concentration

Table 2 White Blood Cells Parameters

\begin{tabular}{lcccc}
\hline Groups & $\begin{array}{c}\text { WBC } \\
\left(\mathbf{1 0}^{3} / \boldsymbol{\mu L}\right)\end{array}$ & $\begin{array}{c}\text { Lymphocyte } \\
\mathbf{( \% )}\end{array}$ & Monocyte (\%) & $\begin{array}{c}\text { Granulocyte } \\
\text { (\%) }\end{array}$ \\
\hline Group I & $4.32 \pm 2.00$ & $77.40 \pm 5.63$ & $12.01 \pm 1.98$ & $10.56 \pm 4.46$ \\
Group II & $5.15 \pm 0.08$ & $77.13 \pm 8.74$ & $10.98 \pm 4.67$ & $11.90 \pm 4.79$ \\
Group III & $6.95 \pm 2.02$ & $77.18 \pm 7.61$ & $10.80 \pm 3.79$ & $12.03 \pm 7.56$ \\
Group IV & $5.80 \pm 2.26$ & $79.63 \pm 6.94$ & $9.78 \pm 4.12$ & $10.60 \pm 3.76$ \\
\hline
\end{tabular}

Note: $\mathrm{WBC}=$ white blood cells 
Table 3 Platelets Parameters

\begin{tabular}{lcccc}
\hline Groups & $\begin{array}{c}\text { Thrombocyte } \\
\left(\mathbf{1 0}^{3} / \boldsymbol{\mu L}\right)\end{array}$ & Pct (\%) & MPV (fl) & PDWc (\%) \\
\hline Group I & $494.29 \pm 178.58^{\mathrm{a}}$ & $0.15 \pm 0.05^{\mathrm{a}}$ & $3.10 \pm 0.39$ & $35.17 \pm 1.86$ \\
Group II & $709.25 \pm 96.09^{\mathrm{a}}$ & $0.28 \pm 0.12^{\mathrm{a}}$ & $3.93 \pm 1.29$ & $35.13 \pm 1.89$ \\
Group III & $583.75 \pm 91.55$ & $0.18 \pm 0.03$ & $3.16 \pm 0.33$ & $34.91 \pm 1.81$ \\
Group IV & $604.43 \pm 164.66$ & $0.18 \pm 0.10$ & $2.87 \pm 0.89$ & $34.06 \pm 1.58$ \\
\hline
\end{tabular}

Note: the same letter in superscript at the same column indicates statitically significant $(\mathrm{p}<0.05)$. PCT $=$ platelet crit; MPV=mean platelet volume; PDW=platelet distribution width

(PDW) values did not differ significantly. CGRE administration reduced the value of Pct, although the statistical calculation was not significant.

\section{Discussion}

$\mathrm{CCl}_{4}$ is widely used in industry and has a toxic effect on humans.,20 The induction of $\mathrm{CCl}_{4}$ in animal models is used to investigate the impact of organ damage in the brain and liver. ${ }^{1,20}$ The increase of reactive oxygen mostly facilitates liver damage by $\mathrm{CCl}_{4}$ and further can cause hepatocyte apoptosis. A disruption in lipid metabolism also causes liver damage that leads to the increase of lipid peroxidation. ${ }^{20}$ In the long term, liver necrosis signs appear, and the liver enters the cirrhosis state. Natural products can be used to improve liver conditions and prevent further liver damage. For example, oral soybean consumption reduced hepatocyte apoptosis signs in $\mathrm{CCl}_{4}{ }^{-}$ induction mice. ${ }^{21}$

Liver damage can influence the hematological profile signed by anemia, leucocytosis, and thrombocytopenia. ${ }^{10,11}$ Our study focused on the role of CGRE to improve hematological profile in $\mathrm{CCl}_{4}$-induced liver damage mice model in an acute state. According to the previous study, the assessment of hematological profile was performed after 48 hours of the induction after 4 weeks of oral CGREE treatment.7 After two days of $\mathrm{CCl}_{4}$ induction, the circulation liver enzyme, aspartate transaminase (AST), and alanine aminotransferase (ALT) were dramatically increased, and necrosis signs appeared in the liver histopathologically. 7

The number of RBC, WBC, and thrombocyte did not change after two days of $\mathrm{CCl}_{4}$ injection. These results indicated that hematological profile deterioration, such as anemia, leucocytosis, and thrombocytopenia, resulted from chronic liver damage. This suggestion is supported by previous studies that showed chronic $\mathrm{CCl}_{4}$ injection disrupts the number of RBC. WBC and thrombocyte and the giving of natural products such as Cnidoscolus aconitifolius leave extract, Teucrium polium aqueous extract, and Mangifera indica leave extract can ameliorate the hematological profile. ${ }^{12,13,15}$ Adebayo et al.' ${ }^{22}$ study conducted acute liver damage by administering a solution of $\mathrm{CCl}_{4}$ : olive oil (1:1) with a dose of $2 \mathrm{~mL} / \mathrm{kgBW}$ for four times in consecutive days before treatment. They showed that hemoglobin. RBC and platelet were reduced. However, no studies describe the hematological profile in a single dose of $\mathrm{CCl}_{4}$ injection for an animal model of acute liver damage. Despite our findings, several red blood cell and platelet cell parameters had been disrupted in $\mathrm{CCl}_{4}$-injection mice.

Hct and $\mathrm{MCV}$ were increased in $\mathrm{CCl}_{4}^{-}$ induction mice and decreased after CGRE treatment with a dose of $150 \mathrm{mg} / \mathrm{kgBW}$. The increase of Hct reflecting the increase of the ratio of red blood cells to the blood total volume and correlates with the increase of $\mathrm{MCV}$, that calculated by multiplying Hct by ten and divided by RBC count. ${ }^{23}$ The increase of MCV, suggesting macrocytic anemia. The condition is found in vitamin B12 deficiency or liver disease. ${ }^{23}$ Injection of $\mathrm{CCl}_{4}$ causes disruption in lipid metabolism and further compromise in a lipid bilayer in RBC. CGRE treated mice showed the reduction of MCV and Hct, suggesting antioxidant compounds in CGRE rescued lipid metabolism. MCHC level reflecting the level of hemoglobin in RBC. Hemoglobin is a protein carrier for nutrients and oxygen derived from iron (Fe) metabolism. Considering the normal hemoglobin level and increase the MCV level, the low level of MCHC is secondary to the increase of $\mathrm{RBC}$ volume and less 
likely due to iron deficiency. Improvement of Hct and MCV facilitated by CGRE dose of $150 \mathrm{mg} /$ $\mathrm{kgBW}$ might increase the level of MCHC. Further analysis of the iron level and iron-related protein could confirm this hypothesis.

Thrombocytopenia is commonly found in chronic liver damage conditions both in human and animal models. ${ }^{15,22,24}$ However, the results of the platelet count is not stable. The platelet count was increased in $\mathrm{CCl}_{4}$-induction mice and agreed with the study conducted by Saleh Gazwi and Mahmoud. ${ }^{12}$ However, the increase of platelet count and Pct might cause thrombocytosis leads to organ disruption. A recent study showed that Pct could be used as a predictor of liver fibrosis. ${ }^{25}$ Administration of CGRE before $\mathrm{CCl}_{4}$-induction can protect the liver from further liver damage due to its antioxidant effect indicating Pct's reduction. Liver histopathology and inflammation marker examination are necessary to confirm this hypothesis.

\section{Conclusions}

A CGRE dose of $150 \mathrm{mg} / \mathrm{kgBW}$ can improve MCV, $\mathrm{Hct}$, MCHC platelet, and Pct in $\mathrm{CCl}_{4}$-injection mice. A high antioxidant level in CGRE might facilitate it.

\section{Conflict of Interest}

All authors state there is no conflict of interest in this article.

\section{Acknowledgment}

We want to thank the Universitas Padjadjaran Internal Research Grant supported this study.

\section{References}

1. Ritesh KR, Suganya A, Dileepkumar HV, Rajashekar Y, Shivanandappa T. A single acute hepatotoxic dose of $\mathrm{CCl}_{4}$ causes oxidative stress in the rat brain. Toxicol Rep. 2015;2:891-5.

2. Forman HJ. Reactive oxygen species and $\alpha, \beta$ unsaturated aldehydes as second messengers in signal transduction. Ann N Y Acad Sci. 2010;1203:35-44.

3. Løkke H, Ragas AM, Holmstrup M. Tools and perspectives for assessing chemical mixtures and multiple stressors. Toxicology.
2013;313(2-3):73-82.

4. Anyasor GN, Moses N, Kale O.. Hepatoprotective and hematological effects of Justicia secunda Vahl leaves on carbon tetrachloride induced toxicity in rats. Biotech Histochem. 2020;95(5):349-59.

5. Fujii T, Fuchs BC, Yamada S, Lauwers GY, Kulu Y, Goodwin JM, et al. Mouse model of carbon tetrachloride induced liver fibrosis: histopathological changes and expression of CD133 and epidermal growth factor. BMC Gastroenterol. 2010;10:79.

6. Zhao ZW, Chang JC, Lin LW, Tsai FH, Chang $\mathrm{HC}, \mathrm{Wu} \mathrm{CR}$. Comparison of the hepatoprotective effects of four endemic cirsium species extracts from Taiwan on $\mathrm{CCl}_{4}$-induced acute liver damage in $\mathrm{C}_{57} \mathrm{BL} / 6$ mice. Int J Mol Sci. 2018;19(5):1329.

7. Dewi L. The effect of lecithin on liver function of white rats (Rattus norvegicus) induced carbon tetrachloride. Biomed Eng. 2016;2(1):5-10.

8. Khan RA, Khan MR, Sahreen S. CCl4induced hepatotoxicity: protective effect of rutin on p53. CYP2E1 and the antioxidative status in rat. BMC Complement Altern Med. 2012;12:178.

9. Manzolli ES, Serpeloni JM, Grotto D, Bastos JK, Antunes LM, Barbosa Junior F, et al. Protective effects of the flavonoid chrysin against methylmercury-induced genotoxicity and alterations of antioxidant status, in vivo. Oxid Med Cell Longev. 2015;2015:602360.

10. Lisman T, Caldwell SH, Burroughs AK, Northup PG, Senzolo M, Stravitz RT, et al. Hemostasis and thrombosis in patients with liver disease: the ups and downs. J Hepatol. 2010;53(2):362-71.

11. Pradella $\mathrm{P}$, Bonetto S, Turchetto S, Uxa L, Comar C, Zorat F, De Angelis V, et al. Platelet production and destruction in liver cirrhosis. J Hepatol. 2011;54(5):894-900.

12. Saleh Gazwi HS, Mahmoud ME. Restorative activity of aqueous extract Mangifera indica leaves against $\mathrm{CCl}_{4}$ induced hepatic damage in rats. J Pharm Biomed Anal. 2019;164:1128.

13. Saba AB, Oyagbemi AA, Azeez OI. Amelioration of carbon tetrachloride-induced hepatotoxicity and haemotoxicity by aqueous leaf extract of Cnidoscolus aconitifolius in rats. Niger J Physiol Sci. 2010;25(2):139-47. 14. Yacout GA, Elguindy NM, El Azab EF. 
Hepatoprotective effect of basil (Ocimum basilicum $\mathrm{L}$.) on $\mathrm{CCl}_{4}$-induced liver fibrosis in rats. Afr J Biotechnol. 2012;11(90):15702-11.

15. Rahmouni F, Hamdaoui L, Badraoui R, Rebai T. Protective effects of Teucrium polium aqueous extract and ascorbic acid on hematological and some biochemical parameters against carbon tetrachloride $\left(\mathrm{CCl}_{4}\right)$ induced toxicity in rats. Biomed Pharmacother. 2017;91:43-8.

16. Padma R, Parvathy NG, Renjith V, Rahate KP. Quantitative estimation of tannins, phenols and antioxidant activity of methanolic extract of Imperata cylindrica. Int J Res Pharm Sci. 2013;4(1):73-7.

17. Dhianawaty D, Ruslin, Syamsunarno MRAA, Hamimah H. Kandungan total flavonoid dari ekstrak metanol akar Imperata cylindrical (L) Beauv. (alang-alang). Talenta Conf Ser Trop Med. 2018;1(3):25-8.

18. Khyade VB, Pawar SS, Sarwade JP. Novel sacrificial medicinal repositories: halfa grass, Desmostachya bipinnata (L.) and cogon grass, Imperata cylindrica (L.). World Sci News. 2018;100:35-50.

19. Anggraeni N, Syamsunarno MRAA, Widyastuti R, Puspitasari IM, Praptama S. Potential dual effect anti-inflammatory and anti-platelet of cogon grass ethanol extract on diabetic mice a preliminary study. J Phys Conf Ser. 2019;1246:012006.

20. Dutta S, Chakraborty AK, Dey P, Kar P, Guha $\mathrm{P}$, Sen S, et al. Amelioration of $\mathrm{CCl}_{4}$ induced liver injury in swiss albino mice by antioxidant rich leaf extract of Croton bonplandianus Baill. PLoS One. 2018;13(4):e0196411.

21. Tejasari M, Shahib N, Iwan D, Sastramihardja HS. Peran kedelai (Glycine max L.) dalam pencegahan apoptosis pada cedera jaringan hati. GMHC. 2014;2(1):15-20.

22. Adebayo AH, Yakubu OF, Adegbite OS, Okubena O. Haematopoietic induction and hepatic protective roles of Hepacare $\AA$ in $\mathrm{CCl}_{4}$-induced hepatic damaged rats. Comp Clin Path. 2017;26(3):679-88.

23. Maner BS, Moosavi L. Mean corpuscular volume[Internet]. Treasure Island: StatPearls Publishing; 2019 [cited 2019 December 15]. Available from: https://www.statpearls. com/ArticleLibrary/viewarticle/24805.

24. LamLambert MP. Platelets in liver and renal disease. Hematology Am Soc Hematol Educ Program. 2016;2016(1):251-5.

25. Wang J, Xia J, Yan X, Yang Y, Wei J, Xiong $\mathrm{Y}$, et al. Plateletcrit as a potential index for predicting liver fibrosis in chronic hepatitis B. J Viral Hepat. 2020;27(6):602-9. 